\title{
FAKTOR DOMINAN PENYEBAB KEMISKINAN RUMAH TANGGA NELAYAN MOTOR TEMPEL DI WILAYAH TANGKAP LEBIH JAWA TIMUR
}

\author{
Anas Tain \\ Kopertis Wilayah VII, dpk Universitas Muhammadiyah Malang \\ Email : anas@umm.ac.id, tain_umm@yahoo.co.id
}

\begin{abstract}
ABSTRAK. Kemiskinan nelayan dinilai meluas dengan tingkat kedalaman kemiskinan yang memprihatinkan. Penelitian ini bertujuan menemukan faktor dominan penyebab kemiskinan rumah tangga nelayan motor tempel di wilayah tangkap lebih Jawa Timur. Penelitian dilakukan dengan metode survei dengan maksud untuk menemukan deskripsi general dan universal atas faktor-faktor penyebab kemiskinan rumah tangga nelayan. Teknik sampling yang digunakan dalam penelitian adalah Multi Stage Cluster Sampling. Hasil penelitian menemukan bahwa sebanyak 61,79 persen rumah tangga nelayan mempunyai sumber pendapatan lain selain dari melaut. Rumah tangga nelayan yang memiliki pendapatan per kapita kurang dari garis kemiskinan sebanyak 61,79 persen. Terdapat 15 faktor dominan penyebab kemiskinan rumah tangga nelayan yang meliputi faktor: (1) kelembagaan yang merugikan nelayan kecil, (2) program yang tidak memihak nelayan kecil, (3) pandangan hidup yang berorientasi akherat saja, (4) keterbatasan sumberdaya, (5) ketidak sesuaian alat tangkap, (6) rendahnya investasi, (7) terikat utang, (8) perilaku boros, (9) keterbatasan musim penangkapan, (10) kerusakan ekosistem, (11) penyerobotan wilayah tangkap, (12) lemahnya penegakan hukum, (13) kompetisi untuk mengungguli nelayan lain, (14) penggunaan alat/bahan terlarang serta (15) perilaku penangkapan. Kemiskinan yang membelenggu rumah tangga nelayan bersifat multidimensional yang menyangkut kemiskinan struktural maupun kemiskinan kultural. Dalam rangka program pengentasan kemiskinan faktor kelembagaan merupakan faktor pertama dan utama yang harus dibenahi.

Kata kunci: kemiskinan, tangkap lebih, pengentasan kemiskinan.
\end{abstract}

\section{THE DOMINANT FACTORS WHICH CAUSE POVERTY AMONG THE OUTBOARD FISHERMAN'S IN THE OVERFISHING AREAS OF EAST JAVA}

ABSTRACT. The fishermen's poverty extends poor. The aims of this research were to find dominant factors which cause poverty among the outboard fishermen's households who lives in the overfishing areas of East Java. This research was conducted by a survey with the aims to find out general and universal description abaut factors causing poverty in fishermen's households. Sampling technique used in this research was Multi Stage Cluster Sampling. The results of this research reveals that 61.79 percents of fishermen's households have other sources of income beside fishing. Fishermen's households with per capita income under poverty line were 61,79 percents. There were 15 dominant factors causing poverty in fishermen's households, consisted of: (1) an institutional which inflicts a loss, (2) a program which doesn't take sides with traditional fishermen's, (3) philosophy of life which is oriented with the beyond, (4) limit of resources, (5) unsuitable catching tools, (6) low investment, (7) debt, (8) wasteful habit, (9) limits of catching fish period, (10) ecosystem damage, (11) occupancy of catching areas, (12) upholding the fragile law, (13) a competition to make a fishermen more superior than the others, (14) illegal tools/materials, (15) catching behavior. Poverty that bound fishermen's households was multidimensional included structural and cultural poverty. In the programs to eradicate poverty, institutional factor was the first and main factor to be arranged.

Key words: poverty, overfishing, eradicate poverty.

\section{PENDAHULUAN}

Kajian akademik dan perdebatan politik tentang pemanfaatan dan pengelolaan sumberdaya milik bersama (commons property), seperti sumberdaya air, hutan, udara dan perikanan untuk kepentingan kesejahteraan masyarakat semakin berkembang sejak awal tahun 1980-an, ketika dominasi negara dalam pengelolaan sumberdaya tersebut justru mengancam kelestarian sumberdaya yang ada dan penduduk lokal semakin tersingkir dari akses 
terhadap sumberdaya yang tersedia di lingkungannya sendiri. Demikian juga halnya dalam perikanan tangkap, beberapa jenis ikan sudah jarang bisa ditangkap dan nelayan kecil semakin tersingkir dari waktu ke waktu serta hidup dalam belenggu kemiskinan.

Kawasan pesisir yang kaya sumberdaya perikanan dengan mayoritas penduduknya bekerja sebagai nelayan, banyak yang merupakan kantong-kantong kemiskinan. Dari masa ke masa, pergulatan masyarakat nelayan melawan ketidakpastian kehidupan khususnya bagi yang melakukan penangkapan di wilayah perairan yang sudah berada dalam keadaan tangkap lebih, terus menggeliat. Untuk mencukupi kebutuhan seharihari rumah tangga nelayan melakukan pekerjaan lain di luar melaut (Tain, 2006). Kelompok masyarakat yang bermukim di wilayah pesisir adalah yang paling menderita dengan taraf kesejahteraan jauh di bawah kelompok masyarakat lainnya (Kusumastanto, 2002).

Kemiskinan nelayan dinilai meluas dengan
tingkat kedalaman kemiskinan yang memprihatinkan. Diperlukan analisis kultural dan struktural secara simultan untuk memberi jalan keluar dalam pengentasan kemiskinan nelayan dan pencapaian sasaran Millennium Development Goals (MDGs) yang dicanangkan pemerintah Indonesia.

Modernisasi perikanan (b/ue revolution) yang telah berlangsung selama ini tidak dapat dipungkiri mengakibatkan banyak perubahan dalam kehidupan sosial ekonomi nelayan. Tetapi tidak semua lapisan masyarakat nelayan dapat menikmati berkah modernisasi perikanan tersebut, terkait dengan ketersediaan modal ekonomi yang ada. Bahkan menurut Kusnadi (2002), setelah seperempat abad kebijakan modernisasi perikanan dilaksanakan tingkat kesejahteraan hidup nelayan tidak banyak berubah secara substantif. Yang terjadi justru sebaliknya, yakni melebarnya kesenjangan sosial ekonomi antarkelompok sosial dalam masyarakat nelayan dan meluasnya kemiskinan.

Pada rumah tangga nelayan miskin untuk bisa mempertahankan hidup, mereka tetap mengekploitasi sumberdaya perikanan yang telah mengalami overfishing bahkan dengan cara yang destruktif sekalipun. Hal ini seperti yang dikatakan Fauzi (2005), kemiskinan di wilayah pesisir memicu destructive fishing yang kemudian mengacaukan matarantai makanan. Penduduk miskin adalah agen dan korban kerusakan lingkungan (Rusastra dan Napitupulu, 2007). Untuk itu diperlukan peningkatan pendapatan rumahtangga nelayan untuk menjamin pembangunan perikanan yang berkelanjutan.

Besarnya potensi sumberdaya perikanan laut Jawa Timur untuk Laut Pantai Utara dengan luas $65.537 \mathrm{~km}^{2}$ memiliki potensi lestari sebesar $214.970,8$ ton (Dinas Perikanan dan Kelautan Jatim, 2006). Dengan menggunakan data produksi perikanan dan besarnya potensi lestari, sejak tahun 2000 produksi ikan wilayah Pantai Utara Jawa Timur telah melampaui batas potensi lestari, dan produktivitas nelayan relatif tetap dan telah mencapai puncaknya pada tahun 2001 (Tain, 2007).

Melihat fenomena kemiskinan nelayan yang tetap belum berhasil dientaskan selama ini, diperlukan kajian mendalam secara simultan dari aspek kultural, struktural dan perikanan laut sebagai sumberdaya milik bersama. Masalah utama dalam penelitian ini adalah faktor dominan apakah yang menyebabkan kemiskinan rumah tangga nelayan kecil di wilayah tangkap lebih Jawa Timur? Sehingga dari generasi ke generasi rumah tangga nelayan kecil terus terbelenggu dalam kemiskinan.

\section{METODE}

Penelitian ini dilakukan dengan metode penelitian survei. Penggunaan metode survei digunakan untuk: (a) penjajagan (eksploratif) atas faktor-faktor penyebab kemiskinan nelayan yang bersumber dari kemiskinan struktural, kultural dan perilaku penangkapan akibat perikanan laut sebagai sumberdaya milik bersama; (b) deskriptif, menjelaskan dan menemukan deskripsi general dan universal atas faktor-faktor penyebab kemiskinan rumah tangga nelayan; (c) penjelasan (explanatory atau confirmatory), menjelaskan hubungan kausal antarfaktor penyebab kemiskinan rumah tangga nelayan.

Teknik sampling yang digunakan dalam penelitian ini adalah Multi Stage Cluster Sampling. Teknik ini digunakan mengingat tidak tersedianya kerangka sampel yang pasti dan begitu banyaknya jumlah rumah tangga nelayan miskin yang hidup di wilayah tangkap lebih Jawa Timur. Hal ini sejalan dengan yang disampaikan Cochran 
(1993), apabila kerangka sampel tidak ada atau terlalu banyak sehingga butuh waktu panjang dan biaya besar untuk penyusunannya, maka penarikan sampel sebaiknya dilakukan melalui metode cluster.

Pada tahap pertama dari seluruh kabupaten/kota di Jawa Timur yang memiliki sumberdaya perikanan tangkap dan telah mengalami tangkap lebih, dipilih 2 kabupaten yang banyak memiliki armada nelayan kecil (motor tempel) $\leq 12 \mathrm{PK}$, dalam hal ini terpilih Kabupaten Lamongan dan Kabupaten Pasuruan. Tahap kedua adalah memilih kecamatan yang kondisi nelayannya dapat mewakili keragaman kondisi nelayan tingkat kabupaten, dalam hal ini dipilih Kecamatan Paciran untuk Kabupaten Lamongan dan Kecamatan Lekok untuk Kabupaten Pasuruan. Tahap ketiga memilih satu desa di masing-masing kecamatan terpilih, yang banyak memiliki rumah tangga nelayan miskin. Dalam hal ini terpilih Desa Paciran Kecamatan Paciran dan Desa Jatirejo Kecamatan Lekok. Dengan mengambil rumah tangga miskin di masing-masing desa sebagai sampel penelitian dapat diperoleh gambaran relasi-relasi sosial secara utuh dalam kehidupan rumah tangga nelayan.

Untuk mendapatkan faktor dominan penyebab kemiskinan rumah tangga nelayan motor tempel digunakan analisis faktor. Faktorfaktor yang diidentifikasi diturunkan dari teori common property untuk perikanan, grand theory kemiskinan yaitu teori modernisasi yang dianut kalangan liberal (kemiskinan kultural) dan teori ketergantungan yang dianut kalangan radikal (kemiskinan struktural). Secara matematis model analisis faktor dirumuskan sebagai berikut (Malhotra,1993):

$X_{i}=A_{i 1} F_{1}+A_{i 2} F_{2}+A_{i 3} F_{3}+\ldots \ldots . .+A_{i m} F_{m}+V_{i} U_{i}$

Dimana:

$\mathrm{X}_{\mathrm{i}} \quad=$ Standarisasi variabel ke- $\mathrm{i}$

$\mathrm{A}_{\mathrm{ij}} \quad=$ Standarisasi koefisien regresi berganda pada variabel i dalam faktor umum $\mathrm{j}$

$\mathrm{F} \quad=$ Faktor umum

$\mathrm{V}_{\mathrm{i}} \quad=$ Standarisasi koefisien regresi

pada variabel i dalam faktor unik i

$\mathrm{U}_{\mathrm{i}} \quad=$ Faktor unik untuk variabel $\mathrm{i}$

$\mathrm{m} \quad=$ Jumlah faktor umum
Sebagai kombinasi linier dari variabel-variabel yang diobservasi dapat dirumuskan sebagai berikut :

$F_{i}=W_{i 1} X_{1}+W_{i 2} X_{2}+W_{i 3} X_{3}+\ldots \ldots . .+W_{i k} X_{k}$

Dimana:

$\mathrm{k}=$ Jumlah variabel

Tahap-tahap dalam melakukan analisis faktor, adalah sebagai berikut :

1. Membuat matrik korelasi atas semua variabel

2. Ekstraksi faktor, yaitu meringkas faktor-faktor inti dengan memilih variabel-variabel yang mempunyai eigenvalue $\geq 1$. Metode ekstraksi yang digunakan adalah Principal Component.

3. Rotasi untuk penyelesaian akhir dengan metode Varimax

4. Sortasi untuk meletakkan faktor berdasarkan urutan besarnya percentage of variance, mulai dari yang tertinggi sampai terendah.

5. Penggunaan hasil analisis untuk interpretasi dan pembuatan kesimpulan.

\section{HASIL DAN PEMBAHASAN}

Kemiskinan pada rumah tangga nelayan setidaknya dapat dikelompokkan menjadi tiga bentuk kemiskinan berdasarkan faktor pembentuknya. Pertama, kemiskinan struktural. Kemiskinan ini diderita oleh segolongan nelayan karena kondisi struktur sosial yang ada menjadikan mereka tidak dapat ikut menggunakan sumber-sumber pendapatan yang sebenarnya tersedia, juga akibat tatanan kebijakan yang lebih menguntungkan golongan pemilik modal (nelayan besar). Kekuatankekuatan di luar rumah tangga nelayan kecil menjadikan mereka terpinggirkan dan hidup dalam belenggu kemiskinan. Jadi persoalannya adalah ketidakmerataan akses pada sumberdaya karena struktur sosial yang ada. Kedua, kemiskinan kultural yang melihat kemiskinan terjadi karena faktor budaya seperti kemalasan yang bersumber pada nilai-nilai lokal yang memang tidak kondusif bagi suatu kemajuan. Kemiskinan ini tidak lepas dari tata nilai yang dianut rumah tangga nelayan yang bersangkutan dalam menjalani hidup. Ketiga, kemiskinan alamiah terjadi di mana kondisi alam yang tidak mendukung mereka melakukan kegiatan ekonomi 
produktif ataupun perilaku produksi yang tidak produktif akibat sifat sumberdaya yang bersangkutan. Dalam konteks masyarakat nelayan, dapat digambarkan akibat laut dipandang sebagai common property dan akses terbuka menjadikan perikanan laut dieksploitasi secara berlebih bahkan dengan alat dan bahan terlarang. Para nelayan berperilaku untuk saling mendahului dan berupaya memperoleh hasil tangkapan lebih banyak dibanding nelayan lain.
Bahkan sebagian dari mereka menggunakan alat atau bahan terlarang tanpa berfikir masalah keberlanjutan sumberdaya ikan yang ada.

Melalui eksplorasi penyebab kemiskinan nelayan yang bersumber dari kemiskinan struktural, kemiskinan kultural dan sifat sumberdaya laut sebagai common property hasil analisis faktor menemukan 15 faktor dominan penyebab kemiskinan rumah tangga nelayan seperti tampak pada Tabel 1 berikut:

Tabel 1. Hasil Analisis Faktor Penyebab Kemiskinan Rumah Tangga Nelayan

\begin{tabular}{|c|c|c|c|}
\hline \multirow[b]{2}{*}{ Faktor } & \multicolumn{3}{|c|}{ Initial Eigenvalues } \\
\hline & Total & $\begin{array}{c}\% \text { of } \\
\text { Variance }\end{array}$ & $\begin{array}{c}\text { Cumulative } \\
\%\end{array}$ \\
\hline 1. Kelembagaan yang merugikan nelayan kecil & 7.603 & 17.280 & 17.280 \\
\hline 2. Program yang tidak memihak nelayan kecil & 3.361 & 7.638 & 24.918 \\
\hline 3. Pandangan hidup yang berorientasi akherat saja & 2.557 & 5.811 & 30.729 \\
\hline 4. Keterbatasan sumberdaya & 2.258 & 5.131 & 35.860 \\
\hline 5. Ketidak sesuaian alat tangkap & 2.100 & 4.773 & 40.632 \\
\hline 6. Rendahnya investasi & 1.856 & 4.218 & 44.850 \\
\hline 7. Terikat utang & 1.673 & 3.803 & 48.653 \\
\hline 8. Perilaku boros & 1.599 & 3.633 & 52.287 \\
\hline 9. Keterbatasan musim penangkapan & 1.526 & 3.469 & 55.756 \\
\hline 10. Kerusakan ekosistem & 1.399 & 3.179 & 58.934 \\
\hline 11. Penyerobotan wilayah tangkap & 1.337 & 3.039 & 61.973 \\
\hline 12. Lemahnya penegakan hukum & 1.222 & 2.776 & 64.749 \\
\hline 13. Kompetisi untuk mengungguli nelayan lain & 1.124 & 2.554 & 67.303 \\
\hline 14. Penggunaan alat/bahan terlarang & 1.050 & 2.387 & 69.690 \\
\hline 15. Perilaku penangkapan & 1.024 & 2.327 & 72.017 \\
\hline
\end{tabular}

Sumber: hasil analisis data primer, 2010.

Ke-15 faktor sebagaimana tampak pada Tabel 1 di atas mampu menjelaskan sebesar 72,017 persen terhadap keseluruhan faktor penyebab kemiskinan rumah tangga nelayan. Faktor yang memiliki nilai eigenvalue lebih tinggi berarti faktor tersebut sifatnya lebih dominan dibanding faktor lainnya. Dengan demikian faktor kelembagaan merupakan faktor paling dominan sebagai penyebab kemiskinan rumah tangga nelayan motor tempel di wilayah tangkap lebih Jawa Timur dengan daya menjelaskan sampai 17,280 persen.

Persoalan kelembagaan ini utamanya terletak pada aspek kelembagaan pemasaran, kegiatan penangkapan dan bagi hasil. Dalam memasarkan hasil tangkapan, posisi tawar nelayan sangatlah lemah. Para nelayan mayoritas telah terikat kepada pedagang perantara (agen) kreditur mereka, dan terpaksa menerima berapapun harga yang diberikan. Nelayan yang tidak terikat utang pun tidak berdaya menghadapi dominasi para pedagang. Nelayan tidak tahu harga, seringkali pada saat ikan diserahkan pada pagi hari hanya diberi uang sekedarnya dulu, baru sore hari dibayar semuanya. Juga ketika hasil tangkapan banyak, harga pada siang hari dibeli dengan lebih murah dibanding harga pagi hari dan terus menurun sampai sore hari. Lembaga formal Tempat Pelelangan Ikan (TPI) dirasa belum mampu mengadakan lelang sebagaimana mestinya. Di salah satu tempat penelitian yaitu Desa Jatirejo Lekok Pasuruan terdapat TPI yang pelabuhannya termasuk kategori Pelabuhan Perikanan Pantai, dimana keberadaan TPI masih belum bisa menjalankan fungsi yang semestinya. TPI hanya menjalankan jasa timbang dan tidak terjadi aktivitas pelelangan yang sebenarnya. 
Bahkan tidak semua nelayan di desa ini menimbangkan ikan hasil tangkapan di TPI, tetapi langsung dibawa ke tempat agen mereka.

Belum berfungsinya TPI bahkan juga terjadi di TPI besar yang pelabuhannya termasuk kategori Pelabuhan Nusantara seperti di TPI Prigi, sebagaimana dikemukakan Siswanto (2008a). TPI tidak berfungsi sebagai tempat pelelangan ikan dan tidak ada pelelangan ikan di TPI, yang ada hanya sekedar persinggahan ikan, penimbangan ikan dan pembelian ikan oleh tengkulak ke nelayan.

Lebih lanjut Siswanto (2008b), menemukan adanya salah urus manajemen dalam TPI yang dilakukan oleh pengelola antara lain: (1) tidak menggunakan otoritas, justru bekerjasama dengan pedagang sehingga menjadi tunakuasa; (2) tidak menjalankan proses lelang; (3) menanyakan harga ikan ke pedagang, tidak menetapkan standar (batas atas batas bawah) harga ikan; (4) tidak mengusahakan persaingan bebas yang adil dalam transaksi perdagangan ikan; (5) tidak membuat dan memberlakukan aturan mekanisme hubungan antar stakeholders dalam TPI, membiarkan pedagang membuat aturan sendiri yang mengejawantah sebagai pasar gelap untuk mengamankan kepentingannya, termasuk memperoleh keuntungan maksimal. Transaksi perdagangan ikan dalam lembaga ekonomi formal bentukan negara ini mengikuti hukum pasar gelap. TPI adalah bagian dari masalah, bukan solusi kemiskinan nelayan.

Aspek lain dari faktor kelembagaan penyebab kemiskinan rumahtangga nelayan adalah tekait kelembagaan produksi, yaitu tidak mampu menangkap jenis ikan yang muncul secara berkelanjutan. Akibat keterbatasan jenis alat tangkap yang dimiliki nelayan kecil tidak mampu menyesuaikan diri untuk bisa menangkap ikan sesuai musim ikan yang ada. Sepanjang tahun alat tangkap yang dipakai tetap saja, walaupun jenis ikan yang muncul silih berganti sesuai musimnya. Kondisi demikian menjadikan hasil tangkapan nelayan kecil menjadi sedikit. Seharusnya nelayan selalu menyesuaikan alat tangkapnya dengan karakteristik ikan yang sedang muncul sebagaimana telah dilakukan oleh para nelayan di wilayah Daerah Istimewa Yogyakarta. Para nelayan di DIY tersebut telah mempunyai pranoto mongso ikan apa yang sedang muncul di laut, dan mereka meyesuaikan alat tangkap yang harus digunakan pada hari tersebut (Kusuma, 2007).

Faktor dominan kedua, penyebab kemiskinan rumahtangga nelayan motor tempel (kecil) adalah program yang tidak memihak nelayan kecil. Berbagai program pembangunan perikanan selama ini dirasa tidak menguntungkan nelayan kecil serta mendorong ekploitasi berlebih atas sumberdaya perikanan yang ada.

Bahwa program-program modernisasi perikanan dirasa lebih menguntungkan nelayan besar dan kurang memperhatikan/merugikan nelayan kecil. Modernisasi peralatan tangkap hanya bisa dinikmati oleh nelayan besar yang memiliki modal kuat dan akses ke pemegang kekuasaan. Sementara kebijakan pemerintah yang mengejar peningkatan produktivitas seringkali mengabaikan kepentingan nelayan kecil. Lebih lanjut hal ini menjadikan kehidupan rumahtangga nelayan kecil semakin terpinggirkan dan hidup dalam kemiskinan. Hal ini sejalan dengan hasil penelitian Tindjabate (2001) di Kabupaten Poso Sulawesi Tengah yang menunjukkan bahwa proses pemiskinan terhadap nelayan tradisional, terjadi dalam konteks kuatnya tekanan-tekanan struktural yang bersumber dari kebijakan pemerintah Indonesia dalam penyelenggaraan pembangunan subsektor perikanan laut.

Faktor dominan ketiga penyebab kemiskinan rumahtangga nelayan adalah pandangan hidup yang berorientasi akhirat saja. Faktor pandangan hidup yang ada pada rumah tangga nelayan adalah suatu pandangan yang lebih berorientasi pada kehidupan di akhirat nanti, sedangkan keseharian di dunia biarlah berjalan apa adanya, tidak perlu terlalu dipikirkan dengan berat tetapi santai saja, menikmati apa yang ada. Karena menurut mereka kaya ataupun miskin itu adalah suatu yang deterministik atas kewenangan distribusi dari Tuhan. Para nelayan ini tidak terlalu memikirkan hidupnya karena yakin pasti bisa hidup sebagaimana terungkap dari pandangan mereka olak delem beto' gek ngakan apapole mennossah tak ngakannah (ulat dalam batu masih makan, apalagi manusia). Dalam menjalani hidup rumah tangga nelayan miskin tersebut tampak terkungkung dalam kultur yang tidak kondusif untuk membawa mereka keluar dari kemiskinan.

Faktor dominan keempat penyebab kemiskinan rumah tangga nelayan adalah 
keterbatasan sumberdaya. Keterbatasan sumberdaya ini menyangkut sumberdaya manusia nelayan sendiri serta sumberdaya modal keuangan yang tidak ada, atau tidak memadai untuk mampu melakukan usaha penangkapan ataupun usaha lain yang lebih menguntungkan. Wawasan dan pengetahuan para nelayan kecil ini relatif terbatas sekitar dunia melaut saja, hal-hal diluar pekerjaan sehari-hari tidak mereka ketahui. Hal ini tidak lepas dari tingkat pendidikan mereka yang juga relatif rendah, dimana sebagian besar hanya sampai sekolah dasar bahkan tidak lulus. Dalam hal ketrampilan kerja, para nelayan kecil ini juga terbatas. Pekerjaan lain selain menangkap ikan di laut tidak banyak mereka kuasai. Hal demikian selain juga karena tingkat pendidikan yang rendah, derajat mobilitas mereka di daratan yang memungkinkan untuk memperoleh pengalaman baru juga rendah. Sehari-hari rutinitas para nelayan kecil tersebut umumnya hanya pergi melaut, dan setelah pulang mengisi waktu istirahat mereka dengan memperbaiki alat tangkap yang rusak, tidur malam hari terus melaut lagi. Terbatasnya ketrampilan yang dimiliki para nelayan kecil selain masalah melaut inilah yang menjadikan diversifikasi usaha non perikanan di kalangan rumah tangga nelayan tidak mudah berjalan. Meski usulan program diversifikasi usaha sebagai upaya mengatasi kemiskinan rumah tangga nelayan banyak disampaikan, tetapi tidak mudah untuk bisa dilaksanakan. Pola-pola pekerjaan sebagai nelayan membatasi aktivitas ke sektor pekerjaan lain.

Dalam hal kemampuan modal keuangan yang dimiliki rumah tangga nelayan kecil juga terbatas, bahkan sebagian dari mereka sama sekali tidak punya. Keterbatasan kepemilikan aset merupakan ciri umum masyarakat miskin termasuk pada nelayan yang antara lain tergambar dari kondisi rumah, alat-alat rumah tangga yang sederhana, lingkungan tempat tinggal yang kumuh serta terlilit utang.

Faktor dominan kelima penyebab kemiskinan rumah tangga nelayan kecil adalah terkait ketidak sesuaian alat tangkap. Pada umumnya nelayan motor tempel ini tidak memiliki aneka jenis alat tangkap, hal ini tampak pada nelayan di daerah penelitian kalau mereka menggunakan jaring maka sepanjang tahun tetap menggunakan jaring tersebut. Bergantinya musim yang ada dimana jenis ikan yang banyak muncul berganti, para nelayan kecil tersebut tidak mampu menyesuaikan alat tangkap yang seharusnya dipakai sesuai musim. Demikian juga halnya akibat tiap hari hanya menangkap dengan alat tangkap yang mereka meliki, mereka tidak dapat menggunakan alat lain. Sejalan dengan hal ini, dalam hal diversifikasi penangkapan ikan Kusnadi (2002) mengemukakan bahwa nelayan tidak dapat melakukan diversifikasi dalam penangkapan ikan karena hal ini membutuhkan keahlian tertentu yang diperoleh melalui proses yang panjang dan modal yang cukup besar. Misalnya, seorang nelayan sampan pancingan ketika sedang tidak musim ikan tongkol, cakalang dan layang, ia tidak akan mudah mengalihkan pekerjaannya untuk menjadi nelayan udang. Baik metode penangkapan maupun fasilitas yang digunakan untuk menangkap jenis ikan yang berbeda itu tidak sama. Masing-masing kristalisasi keahlian membutuhkan proses belajar yang lama. Oleh karena itu, diversifikasi pekerjaan penangkapan ikan (kenelayanan) sangat sulit dilakukan dan beresiko tinggi.

Faktor dominan keenam penyebab kemiskinan rumah tangga nelayan kecil adalah rendahnya investasi. Rendahnya investasi di kalangan nelayan kecil ini tidak lepas dari keterbatasan kemampuan sosial ekonomi rumah tangga nelayan yang bersangkutan. Pola penerimaan rumah tangga yang bersifat harian dengan jumlah yang tidak banyak cenderung menjadikan penghasilan di satu hari habis untuk segala keperluan di hari tersebut. Dalam benak mereka terpikir, toh besuk masih bisa dapat penghasilan lagi dari menangkap ikan. Alam telah memanjakan nelayan untuk tidak berhemat seperti halnya petani. Apalagi musim ikan yang sesuai dengan alat tangkap yang dimiliki nelayan tidak berlangsung sepanjang tahun, menjadikan nelayan kecil ini mengandalkan utang di saat tidak ada hasil tangkapan. Utang tersebut akan dibayar saat hasil tangkapan ikan melimpah, dimana nelayan memiliki penghasilan yang cukup. Keadaan yang demikian menjadikan tingkat investasi untuk meningkatkan kualitas peralatan tangkap di kalangan nelayan kecil rendah.

Nelayan kecil ini pada umumnya merupakan kelompok masyarakat termiskin dan menjadi nelayan dalam waktu yang relatif lama dengan tingkat pendapatan yang tidak pasti, meskipun memiliki resiko yang sangat tinggi. Ini terjadi karena menjadi nelayan tidaklah semata sebagai matapencaharian (livelihood), tetapi sudah merupakan satu-satunya jalan hidup (way of life). 
Karena itu, secara umum para nelayan tersebut akan mewariskan tradisi menangkap ikan kepada generasi berikutnya meskipun matapencaharian tersebut bersifat marjinal (Goodwin, 1990).

Faktor dominan ketujuh penyebab kemiskinan rumah tangga nelayan kecil adalah terikat utang. Akibat dari pendapatan yang terbatas dan tidak pasti, kehidupan rumah tangga nelayan kecil tidak lepas dari persoalan utang. Untuk memenuhi kebutuhan pokok sehari-hari serta keperluan lain yang mendesak seperti biaya berobat seringkali harus utang kepada pihak lain. Biasanya nelayan pandhiga berutang pada juragan ataupun pedagang (agen), sedangkan nelayan pemilik meminjam ke pedagang. Juga untuk keperluan bahan pangan, rumah tangga nelayan kecil tersebut seringkali berutang di tokotoko atau kios.

Utang yang diberikan pedagang (agen) ke seorang nelayan, membuat nelayan tersebut terikat harus menjual hasil tangkapan ikannya ke pedagang (agen) yang bersangkutan. Sementara harga hasil tangkapan dihargai lebih murah sampai $20 \%$ dari harga pasar. Akibat pembelian ikan yang murah ini, tiap hari pedagang bisa memperoleh keuntungan besar. Para pedagang tetap berusaha agar nelayan tetap terikat utang dengan menawarkan pinjaman untuk perbaikan rumah, pembelian perabot rumah tangga, biaya khitanan ataupun untuk pesta perkinahan anak nelayan. Demikian pula, jika nelayan harus berutang ke toko atau kios, harga barang dinaikkan. Nelayan mau menerima praktik ini karena terpaksa, dan tidak memiliki alternatif lain. Pendapatan nelayan kecil yang sudah tidak seberapa menjadi lebih sedikit lagi dengan praktik utang dikalangan nelayan.

Faktor dominan kedelapan penyebab kemiskinan rumah tangga nelayan kecil adalah perilaku boros. Meskipun kehidupan rumah tangga nelayan kecil umumnya memiliki keterbatasan aset dan sumber penghasilan utama hanya dari melaut, dalam hidup sehari-hari cenderung boros. Berapapun yang diperoleh dari hasil melaut banyak dihabiskan di hari tersebut atau hannya beberapa hari. Secara tidak langsung hal ini akibat alam pikir yang ada di benak nelayan, toh besuk masih bisa mendapat uang lagi dari hasil melaut. Berdasarkan data time series selama 30 hari berturut-turut tampak bahwa pola konsumsi rumah tangga meningkat disaat hasil tangkapan lebih banyak.
Kehidupan rumah tangga nelayan kecil yang cenderung boros dalam membelanjakan pendapatan yang diperolehnya sejalan dengan apa yang disampaikan Kusdiantoro (2005) bahwa salah satu kebijakan yang diperlukan untuk mengatasi kemiskinan nelayan adalah perlunya perubahan perilaku masyarakat nelayan sendiri. Perubahan perilaku ini diharapkan dapat mengubah pola-pola tradisional yang cenderung konsumtif menjadi terencana dan teratur. Pendapat tentang nelayan sebagai masyarakat yang cenderung boros ini juga telah disampaikan oleh banyak pihak.

Faktor dominan kesembilan penyebab kemiskinan rumah tangga nelayan kecil adalah keterbatasan musim penangkapan. Kondisi alam dan fluktuasi musim menyebabkan nelayan tidak dapat melaut sepanjang tahun. Ada saatnya musim dimana nelayan tidak berani melaut karena ombak yang besar yang dapat membahayakan keselamatan jiwa, ataupun musim paceklik tidak ada/sedikit ikan. Dalam kondisi tidak ada penghasilan seperti ini untuk memenuhi kebutuhan rumah tangga adalah melalui utang. Utang akan dibayar saat kondisi alam membaik dan hasil tangkapan ikan melimpah. Prasyaratnya adalah nelayan harus menjual hasil tangkapannya kepada pedagang (agen) pemberi pinjaman dengan harga ditentukan pedagang. Jika pada saat musim ikan ternyata nelayan tidak memperoleh hasil yang memuaskan, utang tidak mampu dilunasi dan menumpuk karena musim paceklik berikutnya nelayan kembali mengutang. Pola hubungan nelayan-pedagang ini sering disebut sebagai hubungan patron-client (patronase). Pola hubungan tradisional yang bersifat patron-client dikembangkan masyarakat nelayan untuk mengantisipasi ketidakpastian pendapatan dan menjaga kelangsungan hidup. Pola hubungan ini mengakibatkan kemiskinan struktural nelayan menjadi lestari.

Faktor dominan ke-10 penyebab kemiskinan rumah tangga nelayan kecil adalah kerusakan ekosistem. Semakin langkanya sumberdaya ikan, justru disikapi oleh sebagian nelayan dengan menggunakan alat atau bahan terlarang yang dapat mengancam kelestarian ikan. Mereka beralasan jika tidak menggunakan alat atau bahan terlarang tersebut, tidak akan bisa mendapat hasil tangkapan ikan dan kebutuhan rumah tangga mereka tidak terpenuhi, disamping itu ikan di laut tidak akan habis. Nelayan miskin 
memang sebagai agen sekaligus korban dari kerusakan ekosistem laut yang dapat mengancam kelestarian sumberdaya ikan.

Tekanan terhadap sumber daya pesisir sering diperberat oleh tingginya angka kemiskinan di wilayah tersebut. Kemiskinan sering pula menjadi lingkaran karena penduduk yang miskin sering menjadi sebab rusaknya lingkungan pesisir, namun penduduk miskin pula yang akan menanggung dampak dari kerusakan lingkungan. Kondisi tersebut tidak mengherankan jika praktik perikanan yang merusak masih sering terjadi di wilayah pesisir.

Faktor dominan ke-11 penyebab kemiskinan rumah tangga nelayan kecil adalah penyerobotan wilayah tangkap. Kemiskinan rumah tangga nelayan kecil selain karena semakin langkanya sumberdaya ikan yang ada akibat eksploitasi berlebih juga diakibatkan oleh masuknya nelayan daerah lain ke wilayah tangkap nelayan yang bersangkutan. Nelayan pendatang biasanya memiliki peralatan tangkap yang lebih modern dibanding nelayan setempat. Akibatnya hasil tangkapan nelayan setempat yang sudah semakin menurun menjadi jauh lebih sedikit. Persoalan ini sering menyulut konflik antar nelayan, terlebih di era otonomi daerah ini masing-masing kelompok nelayan mendapat dukungan dari pemerintah daerahnya. Terkait hal ini seluruh stakeholders perlu berdialog untuk merumuskan norma-norma kolektif dan strategi mengelola sumberdaya perikanan secara berkelanjutan.

Masuknya nelayan luar daerah yang menyebabkan semakin tersingkirnya nelayan setempat juga disampaikan Karim (2005), bahwa salah satu penyebab mengapa nelayan NTT menangkap ikan sampai memasuki perairan Australia adalah ketidakmampuan mereka bersaing dengan armada penangkapan modern baik legal maupun ilegal yang beroperasi di perairan Arafuru. Padahal perairan ini dulunya menjadi tempat mereka menangkap ikan. Beroperasinya armada perikanan modern pada akhirnya memarjinalkan nelayan tradisional yang menggunakan motor tempel ataupun perahu bermotor.

Faktor dominan ke-12 penyebab kemiskinan rumah tangga nelayan kecil adalah lemahnya penegakan hukum. Dalam upaya pengendalian terhadap kegiatan - kegiatan pemanfaatan sumberdaya ikan, pemerintah telah menetapkan beberapa ketentuan hukum yang menyangkut pengaturan penggunaan beberapa jenis alat penangkap ikan dan cara operasinya. Ada beberapa jenis alat penangkap ikan dan cara penangkapan yang secara khusus dilarang dan dioperasikan di beberapa wilayah bahkan diseluruh wilayah perairan Indonesia seperti penggunaan pukat harimau, pengoperasian pukat udang dan pukat ikan yang ditarik oleh 2 (dua) kapal, penggunaan bahan peledak, racun dan aliran listrik untuk menangkap ikan.

Untuk mewujudkan kelestarian sumberdaya ikan diperlukan upaya penegakan hukum secara konsisten dan bertanggungjawab. Gejala kompradorisasi dalam pengelolaan sumberdaya laut, yang menguntungkan segelintir orang dan melanggengkan kemiskinan struktural sedapat mungkin segera dihilangkan. Hal ini seperti apa yang disampaikan Karim (2005) bahwa kemiskinan struktural nelayan di Indonesia juga berkaitan dengan tindakan ekspolitasi sumberdaya ikan yang dilakukan oleh pemodal besar dan mendapat dukungan dari penguasa dan aparat keamanan.

Faktor dominan ke-13 penyebab kemiskinan rumah tangga nelayan kecil adalah kompetisi untuk mengungguli nelayan lain. Sejalan dengan wilayah tangkap yang telah mengalami tangkap lebih dari tahun 2000, dari waktu ke waktu dirasa pendapatan nelayan semakin menurun. Pendapatan hasil melaut yang semakin menurun ini, melecut timbulnya kompetisi antarnelayan dalam upaya mendapatkan hasil tangkapan. Nelayan yang memiliki cukup modal berusaha memiliki alat tangkap yang lebih baik dari nelayan lainnya. Hal ini sejalan dengan apa yang disampaikan Kusnadi (2003), bahwa kelangkaan sumberdaya perikanan telah mendorong terjadinya kompetisi antarkelompok nelayan dalam memperebutkan sumberdaya perikanan yang ada. Faktor lain yang ikut menyumbang terhadap peningkatan kompetisi adalah kemiskinan dan keterbatasan sosial ekonomi yang tidak kunjung sirna yang mewarnai kehidupan nelayan.

Selama penelitian dari komunikasi dengan responden terasa oleh peneliti adanya rasa kecemburuan ataupun tidak senang atas nelayan lain yang menggunakan alat yang berbeda. Hal ini sejalan dengan apa yang disampaikan Siswanto (2008a) tentang keharmonisan semu dalam hubungan antar nelayan, tengkulak di Prigi 
Trenggalek. Meskipun pada tingkat permukaan tidak terdapat masalah, tidak ada perselisihan terbuka dan keributan yang dipertontonkan ke publik tetapi pada tingkat kesadaran terdalam atau di jagat mikro komunitas nelayan terdapat ketegangan diantara mereka. Hubungan sosial dan ekonomi antar nelayan pada dasarnya berlangsung dalam keharmonisan semu.

Faktor dominan ke-14 penyebab kemiskinan rumah tangga nelayan kecil adalah penggunaan alat/bahan terlarang. Selain wilayah tangkap yang telah mengalami tangkap lebih, kelangkaan sumberdaya ikan yang ada juga dipicu oleh penggunaan bahan-bahan terlarang yang merusak ekosistem laut. Akibat semakin langkanya sumberdaya ikan yang ada sebagian nelayan untuk tetap mendapatkan hasil tangkapan memilih menggunakan bahan terlarang seperti bom ikan. Untuk mengejar kepentingan jangka pendek, mereka menangkap ikan dengan bom yang justru mengancam keberlanjutan sumber matapencaharian mereka di masa mendatang.

Faktor dominan ke-15 penyebab kemiskinan rumah tangga nelayan kecil adalah perilaku penangkapan. Sebagaimana telah dikemukakan dengan semakin langkanya sumberdaya ikan yang ada, kompetisi antar nelayan untuk bisa mendapatkan hasil tangkapan semakin meningkat. Salah satu bentuk yang ada adalah perilaku penangkapan untuk berusaha melaut lebih awal dibanding nelayan lain. Mengingat laut sebagai sumberdaya milik bersama, semua dapat memanfaatkan, maka perilaku untuk bisa mendahului nelayan lain adalah sesuatu yang wajar. Apalagi di antara nelayan telah berkembang kebiasaan jika ada yang mendapatkan hasil tangkapan yang banyak, nelayan lain bertanya dimana tempat mendapatkan ikan yang banyak tersebut. Nelayan-nelayan lain biasanya akan menangkap ikan di wilayah dimana teman mereka mendapatkan hasil tangkapan yang banyak. Jika sebelum tahun 2000 kebanyakan nelayan di daerah penelitian berangkat setelah subuh, saat ini jam 01.00 sudah banyak yang berangkat melaut.

Perilaku penangkapan ini sejalan dengan apa yang disampaikan Gordon (1986) bahwa, dalam perikanan laut sumberdaya alam bukanlah milik perorangan; dengan demikian bunga yang dihasilkannya tidak seorangpun dapat menguasainya sendiri. Setiap nelayan bebas untuk menangkap ikan di setiap tempat yang disukainya. Akibatnya ialah suatu pola persaingan di antara para nelayan yang mencapai puncaknya dalam menghabiskan bunga daerah-daerah perikanan intramarjinal. Besar kemungkinan beberapa daerah penangkapan akan dieksploitasi pada tingkat produktivitas marjinal yang negatif. Apa yang terjadi ialah bahwa bunga yang dapat dihasilkan oleh daerah-daerah intramarjinal, terbagi habis karena kesalahan alokasi upaya penangkapan. Inilah sebabnya para nelayan tetap miskin, kendatipun sesungguhnya sumberdaya perikanan laut merupakan yang terkaya.

\section{SIMPULAN}

Terdapat 15 faktor dominan penyebab kemiskinan rumah tangga nelayan kecil di wilayah tangkap lebih yaitu faktor : kelembagaan yang merugikan nelayan kecil, program yang tidak memihak nelayan kecil, pandangan hidup yang berorientasi akherat saja, keterbatasan sumberdaya, ketidak sesuaian alat tangkap, rendahnya investasi, terikat utang, perilaku boros, keterbatasan musim penangkapan, kerusakan ekosistem, penyerobotan wilayah tangkap, lemahnya penegakan hukum, kompetisi untuk mengungguli nelayan lain, penggunaan alat/bahan terlarang serta perilaku penangkapan.

Ke-15 faktor dominan tersebut mampu menjelaskan sebesar $72,017 \%$ terhadap keseluruhan faktor penyebab kemiskinan rumah tangga nelayan.

Dari 15 faktor dominan penyebab kemiskinan rumah tangga nelayan dapatlah diketahui bahwa pada hakekatnya kemiskinan yang membelenggu rumah tangga nelayan adalah kemiskinan yang menyangkut multidimensi.

Dalam mengkaji kemiskinan rumah tangga nelayan haruslah dilandasi dengan teori modernisasi (kemiskinan kultural), teori ketergantungan (kemiskinan struktural) dan teori common property untuk perikanan secara simultan.

Untuk memberdayakan rumah tangga nelayan miskin keluar dari belenggu kemiskinan diperlukan program yang berkelanjutan dan runtut sesuai kekuatan pengaruh faktor penyebab kemiskinan. 
Introduksi peralatan tangkap harus diikuti sosialisasi pentingnya pengelolaan sumberdaya ikan secara lestari.

\section{DAFTAR PUSTAKA}

Cochran, W.G. 1993. Sampling Techniques, Third Edition, New York: John Wiley \& Sons, Inc.

Fauzi, Akhmad. 2005. Kebijakan Perikanan dan Kelautan: Isu, Sintesis, dan Gagasan, Jakarta: PT Gramedia Pustaka Utama.

Goodwin, James R. 1990. Crisis in the World's Fisheris: People Problem and Policies. California: Standford University Press.

Gordon, H.S. 1986. Teori Ekonomi Tentang Sumber Daya Milik Bersama: Perikanan. Dalam Ekonomi Perikanan Dari Teori Ekonomi ke Pengelolaan Perikanan, Ed,: Ian R. Smith dan Firial Marahuddin, Jakarta: PT Gramedia.

Karim, Muhamad. 2005. Benang Kusut Kemiskinan Nelayan, Republika, 01 Juni 2005.

Kusdiantoro. 2005. Pilpres dan Nasib Nelayan, http://www.pikiran-rakyat.com/cetak /0804/30/teropong/lainnya1.htm

Akses [21/12/2005].

Kusuma, Mawar 2007. Suwarman, Pranata Mangsa untuk Nelayan, Kompas, Sabtu, 14 Juli 2007.

Kusnadi. 2002. Konflik Sosial Nelayan Kemiskinan dan Perebutan Sumber Daya Perikanan, Yogyakarta: LKiS.

Kusnadi. 2003. Akar Kemiskinan Nelayan, Yogyakarta: LKiS.
Kusumastanto, T. 2002. Reposisi "Ocean Policy" Dalam Pembangunan Ekonomi Indonesia di Era Otonomi Daerah. Orasi Ilmiah Guru Besar, Bogor: Institut Pertanian Bogor.

Malhotra, Naresh K. 1993. Marketing Research, New Jersey, USA: Printice-Hall Inc.

Rusastra, I Wayan dan Togar A. Napitupulu. 2007. Karakteristik Wilayah dan Keluarga Miskin di Pedesaan, Makalah Seminar Nasional Meningkatkan Peran Sektor Pertanian Dalam Penanggulangan Kemiskinan, Bogor: Pusat Analisis Sosial Ekonomi dan Kebijakan Pertanian, Departemen Pertanian.

Siswanto, Budi. 2008a. Kemiskinan dan Perlawanan Kaum Nelayan, Surabaya: Laksbang Mediatama.

Siswanto, Budi. 2008b. Nelayan dan Politik Perikanan, Surabaya: Papyrus.

Tain, Anas. 2006. Analisis Distribusi Pendapatan Rumah Tangga Nelayan (Studi Kasus di Desa Blimbing Kecamatan Paciran Kabupaten Lamongan). Program PHK A2 Fakultas Pertanian, Universitas Muhammadiyah Malang.

Tain, Anas 2007. Analisis Perkembangan Produksi Perikanan Tangkap Jawa Timur, Program PHK A2 Fakultas Pertanian, Universitas Muhammadiyah Malang.

Tindjabate, Cristian. 2001. Kemiskinan Pada Masyarakat Nelayan: Studi Tentang Proses Pemiskinan dan Strategi Bertahan Hidup Masyarakat Nelayan Tradisional di Daerah Kabupaten Poso Propinsi Sulawesi Tengah (Disertasi) Yogyakarta: Program Pasca Sarjana Universitas Gadjah Mada. 